\title{
Role of Travel Motivations, Perceived Risks and Travel Constraints on Destination Image and Visit Intention in Medical Tourism Theoretical model
}

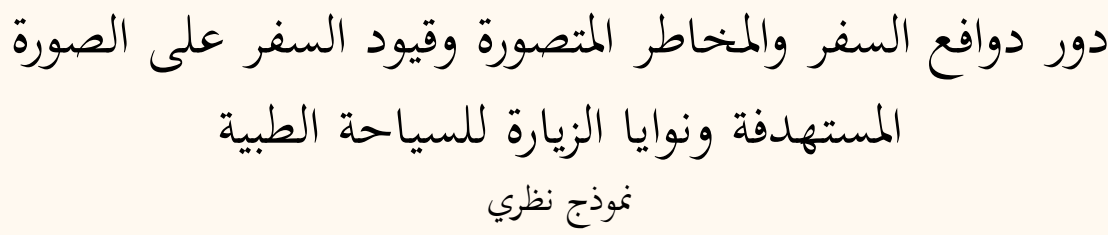

محمد جمال خان، شانكر شيلليه، محمد صبري هـارون، سهريش أحمد

ABSTRACT: Travel motivations, perceived risks and travel constraints, along with the attributes and characteristics of medical tourism destinations, are important issues in medical tourism. Although the importance of these factors is already known, a comprehensive theoretical model of the decision-making process of medical tourists has yet to be established, analysing the intricate relationships between the different variables involved. This article examines a large body of literature on both medical and conventional tourism in order to propose a comprehensive theoretical framework of medical tourism decision-making. Many facets of this complex phenomenon require further empirical investigation.

Keywords: Medical Tourism; Travel; Trends; Motivation; Risks; Intentions; Theoretical Model.

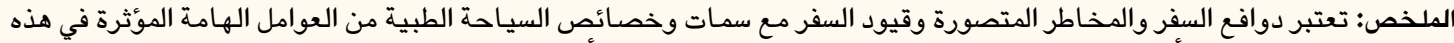

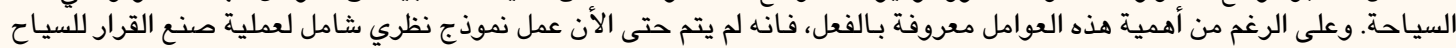

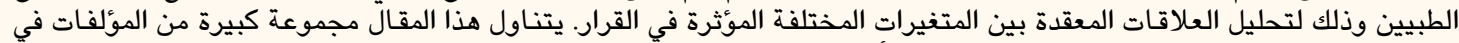

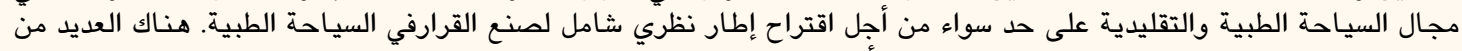

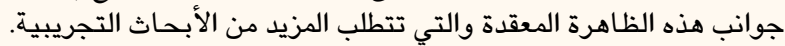

$$
\begin{aligned}
& \text { الكلمات المفتاحية: السياحة الطبية؛ السفر؛ اتجاهات؛ التحفيز؛ المخاطر؛ النوايا؛ نموذج نظري. }
\end{aligned}
$$

$\mathrm{M}$ EDICAL TOURISM COMMONLY REFERS TO the act of travelling to a foreign country in order to seek healthcare services. ${ }^{1}$ Until recently, the concept of medical tourism was relatively unknown as it was difficult to envisage a connection between the two very different areas of international travel and medical care; however, the rate of medical tourism has sharply accelerated in the last two decades. ${ }^{2}$ Modern medical tourism is characterised by an influx of middle-class patients from industrialised countries and affluent patients from less economically developed countries making use of the medical services available at foreign destinations. Although medical tourism is an economically successful business venture for many countries, exact data regarding its market size and revenue remain largely unavailable. ${ }^{3}$ According to the medical tourism guidebook Patients Beyond Borders, approximately 14 million medical travellers travelled abroad for treatment in 2015; as such, it was estimated that the medical tourism market was worth USD \$45.5-72 billion. ${ }^{4}$ Another source reported that over 19 million trips for the purposes of medical tourism were made in 2005 for a total value of USD $\$ 20$ billion, amounting to $2.5 \%$ of the total annual tourism volume; this was estimated to increase to 40 million trips per annum and comprise $4 \%$ of the total annual tourism volume by 2010.5

Economically, medical travel has benefited several southern countries, including India, Cuba, Costa Rica, Mexico, Malaysia, Thailand, and South Africa, where the cost of medical procedures is extremely low compared to those of more northern countries. ${ }^{6}$ It is estimated that the annual number of Americans travelling abroad for healthcare services will increase to 23 million by 2017.7 However, the number of medical tourists moving between southern countries is also extremely high; approximately 500,000 medical tourists travelled to South Africa from other African 


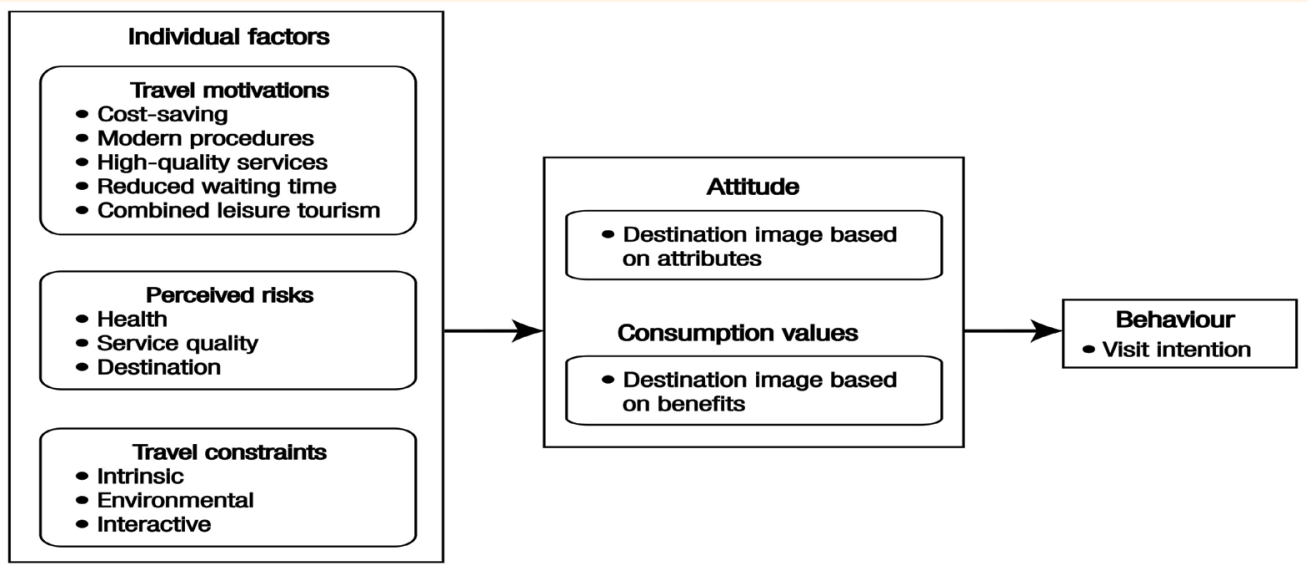

Figure 1: Theoretical model of medical tourism decision-making. Note the unidirectional arrows which indicate the complexity of the relationships between the factors in the model.

countries in 2009 and over half of the medical tourists in Malaysia $(670,000)$ and Singapore $(850,000)$ in 2012 were from Indonesia. ${ }^{8,9}$ Thailand also receives a large number of medical travellers from neighbouring countries (2.5 million in 2012). ${ }^{10}$ Moreover, approximately 100,000 people from East Africa are estimated to travel to India every year for medical purposes. ${ }^{11}$ Among all global medical tourists, $40 \%$ travel due to a lack of advanced technology in their own country, 32\% travel to seek better quality services and $12 \%$ travel for lower-cost treatments. ${ }^{12}$

Although a number of studies exploring different aspects of medical tourism have recently been published, empirical insight into medical tourism is still lacking. ${ }^{6,9}$ Much of the available literature is exploratory, anecdotal in nature and highly speculative or comprised of review articles exploring different aspects of medical tourism. ${ }^{13-16}$ Some studies have attempted to establish relationships between various factors, such as motivation, service quality, service satisfaction and revisit intention..$^{10,17,18}$ Recently, models to explain destination selection by medical tourists have been proposed; however, these models are limited to a specific source or destination and are not comprehensive. ${ }^{19,20}$ Fetscherin et al. developed a scale to validate the causative factors in destination decision-making, but failed to explain these factors from the traveller's perspective. ${ }^{6}$ Other models to explain the decision-making processes of medical travellers do not consider geographical location, country of origin or socioeconomic status. ${ }^{6,8,14,16,18}$ These models are mainly based on travel motivations, perceived risks and destination image and characteristics, factors which are then linked to destination selection and visit intention. ${ }^{21,22}$ Other researchers have also proposed travel constraints among the factors influencing individual decision-making. ${ }^{23}$
Based on a thorough review of the literature, the current article introduces a comprehensive theoretical framework on medical tourism decision-making, combining causative factors related to the characteristics of both the destination and the tourist [Figure 1]. This proposed framework may help in enhancing understanding of the behaviour of medical tourists and assist destination marketing specialists in formulating specific strategies to attract medical tourists.

\section{Travel Motivations}

Motivation can be defined as an internal psychological force arising from an unsatisfied need, which subsequently pushes individuals to engage in a specific need-fulfilling behaviour or activity. ${ }^{24}$ In tourism research, motivation is considered a major force in compelling tourist behaviours. ${ }^{25}$ Psychosocial motivations in tourist behaviour can be divided into 'push' and 'pull' factors leading individuals to travel. ${ }^{22,26}$ Motivations in medical tourism differ from those in leisure tourism, based on the specific needs of these types of travellers.

Medical tourists from northern countries often travel for a variety of reasons, including cost-saving purposes or because of the prohibitive expense of healthcare services in their own country; access to procedures banned in their home country; cultural or family reasons; in order to combine a minor medical procedure with leisure travel; and the long waiting lists for procedures in countries with publicly-funded healthcare systems, such as the UK and Canada.,16 Crooks et al. categorised the travel motivations of tourists from northern countries as either procedurerelated, travel-related or cost-related..$^{27}$

In contrast, the travel motivations of medical tourists from southern countries differ. Medical 
tourists from Southeast Asia often travel abroad because of their mistrust in the quality of local medical services or the level of staff professionalism. ${ }^{28}$ On the other hand, medical tourists from the Middle East reportedly travel abroad due to family pressure and the misconception that services at home are inadequate. ${ }^{29}$ In most Gulf Cooperation Council countries, health services are entirely government-funded and free to nationals; for this reason, patients may not value the services available. ${ }^{30}$ Rokni et al. found that Irani patients were highly motivated to travel to a particular destination because of their emotional attachment to the doctors, hospitals or the destination. ${ }^{31}$ A decision to undergo treatment abroad can reflect broader social values and experiences; for instance, it is a common view in the Yemeni community that individuals have a responsibility to ensure the health of their family members, even if doing so is very expensive. ${ }^{32}$ Travellers from Africa often visit other countries for medical purposes because of the unavailability of modern procedures and diagnostic services, a mistrust of local service providers and the poor state of public healthcare systems. ${ }^{8}$ Individuals from various East African countries travel to India because they cannot afford the high medical fees at home. ${ }^{11}$ Overall, most tourists from southern countries travel principally to obtain medical care, with a very minor leisure component to their trip. ${ }^{3}$

\section{Perceived Risks}

The perceived probability that an action may expose an individual to danger can influence travel decisions if the perceived danger is deemed to be beyond an acceptable level. ${ }^{33}$ In tourist decision-making, perceived risks hold the greatest influence in terms of destination selection. ${ }^{34}$ Medical services are considered to be credence goods as their quality cannot be accurately ascertained, even after usage; as such, the associated risk of utilising medical services is high. ${ }^{35}$ Furthermore, patients may be vulnerable to other risks when using medical services outside of their own country, including health, service quality, destination, travel and pre- and postoperative risks. ${ }^{36}$ While staying at their travel destination, medical travellers may contract an infection before or after the medical procedure, develop thrombosis during long-haul flights which might slow down wound healing or be affected by the unavailability of blood transfusion components during the recuperation process. ${ }^{37}$ Specifically, taking long-haul flights while in poor health can result in both physical and psychological pain; for many patients, existing conditions may worsen if they undertake journeys with multiple stopovers. ${ }^{32}$

The likelihood of compensation in the case of complications has also been researched. ${ }^{38}$ Most healthcare service providers willing to provide services to medical tourists are private and, as such, there are no enforced guidelines or control mechanisms in place to monitor treatment practices. ${ }^{38}$ This can lead to a situation whereby unnecessary treatments are prescribed for reasons of monetary gain rather than medical necessity. Undergoing a procedure that is illegal in their home country can also expose medical travellers to unknown risks. ${ }^{2}$ More importantly, making medical tourism decisions primarily as a result of cost-related motivations can be risky and may lead to negative outcomes. Some patients have been known to suffer from psychological and emotional distress while recovering from a procedure in a foreign destination. ${ }^{39}$ Medical tourists from southern countries are usually considered more vulnerable to certain risks, given their often insufficient knowledge, limited resources and the potential prejudices they may face, as well as their vulnerability to various crimes, such as robbery or physical and sexual assault. ${ }^{40}$

Another risk of medical tourism is an increase in patient-physician mistrust. After treatment, medical tourists often return to their home country with new and potentially hazardous prescriptions without effective guidelines or monitoring of use. Alternatively, they may return just as their disease becomes more advanced and/or incurable, at which point fewer treatment options are available. ${ }^{39,40}$ As such, patients subsequently compare the late-stage treatment received in their home country to the early-stage treatment received at the foreign destination and form negative perceptions of their local health-

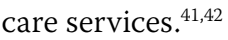

\section{Travel Constraints}

Travel constraints are defined as factors which inhibit either initial or further travel, constrain an individual's ability to maintain or increase the frequency of travel and/or negatively affect their quality of travel..$^{43}$ Hung et al. argued that the existence of travel constraints does not necessarily result in a lack of travelling; their findings indicated that most individuals adopted negotiation measures to counter travel constraints. ${ }^{43}$ Indirect evidence shows that medical tourists face different types of constraints; however, there is a lack of empirical research exploring the travel constraints of medical tourists. 
The travel constraints of individuals with chronic illnesses or disabilities have been categorised as intrinsic (e.g. lack of knowledge, health-related problems, social ineffectiveness and physical or psychological dependency), environmental (e.g. attitudinal, architectural, ecological or transportationrelated problems) and interactive (e.g. skill/challenge incongruities and communication/language barriers). ${ }^{44}$ Short-term illnesses can also restrict the movement of individuals and alter their mental and psychological abilities. ${ }^{45}$ Medical tourists travelling to other countries with the sole aim of acquiring medical services may also face constraints similar to those of individuals with disabilities; a few anecdotal examples in the medical tourism literature support this claim. ${ }^{44}$ One study of Yemeni medical travellers found that many individuals did not possess appropriate knowledge and simply followed advice from their relatives and friends who had travelled earlier. ${ }^{32}$

Existing ailments may also restrict certain patients from travelling, for instance in cases of cardiac, respiratory or orthopaedic conditions. Additionally, current literature on this topic indicates that travellers from southern countries face further constraints in the form of air connectivity, visa processing, local transportation and language barriers. ${ }^{42,46}$ Some medical tourists may also be concerned about the opinions of their friends and family if they choose to use medical services in less economically developed countries. ${ }^{2,47}$

\section{Perceived Destination Image}

Destination image reflects the sum total of an individual's ideas, beliefs, and impressions of a travel destination. ${ }^{48}$ According to Echtner et al., destination image consists of two components: attribute-based and holistic. ${ }^{49}$ Destination image covers attributes common to all destinations, as well as the unique attributes of a specific destination. In a tourism consumer behaviour model, three components of destination image formation are incorporated: awareness formed after acquiring information about a destination, attitudes formed as a result of beliefs and feelings regarding a destination and expectations formed based on the benefits associated with a destination. ${ }^{50}$ Gallarza et al. mentioned that destination image is a mental representation of the attributes and benefits on the part of the traveller. ${ }^{51}$ Two major factors, attributes and benefits, then combine to form the overall destination image.

\section{ATTRIBUTES}

The attributes of a destination are of the utmost importance in influencing the destination image. ${ }^{52}$
The evaluation of a destination is multidimensional and both general as well as specific attributes are important in its promotion..$^{53}$ Tasci et al. argued that the image of a destination can be conceptualised in terms of cognitive components based on the attributes of that destination. ${ }^{54}$ Measurements of a cognitive image vary according to the destination; however, descriptiveness, direct observability and measurability of a cognitive image have been established as the best tools to assess the uniqueness of a destination. ${ }^{55}$

Medical tourism destination images are formed from the various tangible characteristics-both medical and non-medical-of a destination. Tangible attributes can include the price, quality of medical services, type of services offered, accreditation of the institutions or hospitals, credentials of the doctors or healthcare providers, supportive services, quality of the infrastructure, the socioeconomic environment and determinants of personal safety and security. $2,56,57$ As such, some destinations are recognised for their cheap and high-quality services (e.g. India) whereas others are known for combining medical procedures with leisure, such as Thailand and the Caribbean; some destinations, such as Singapore, offer expensive but highly sophisticated services..$^{58,59}$

Destination image formation can also be affected by word-of-mouth. Most travellers, especially from southern countries, select medical tourism destinations and doctors based on personal recommendations from their friends and relatives. ${ }^{60} \mathrm{Yu}$ et al. have reported that medical tourists emphasise costsaving, sociocultural factors, medical facilities and professional and leisure tourism opportunities when selecting a destination. ${ }^{61}$ Musa et al. found that excellent medical and support services were important pull factors in destination selection. ${ }^{28}$ Other studies have indicated that religious beliefs and emotional attachments can also influence the destination choices of medical tourists, especially among those from southern countries. ${ }^{28,29}$

\section{BENEFITS}

Destination image formation is not necessarily solely influenced by tangible destination attributes; researchers have noted that the benefits associated with a destination can sometimes drive tourists to destinations with negative attributes. ${ }^{62}$ In one study, individuals reported liking one country and disliking another even though the two countries were very similar. ${ }^{63}$ Moutinho argued that the physical attributes of a destination work only as stimuli consistent with certain pre-existing associations, thereby leading to a destination image which is subjective rather than objective..$^{50}$ 
According to Lefkoff-Hagius et al., products have symbolic aspects which determine the degree to which ownership or consumption of the product enhances the image of the consumer. ${ }^{64}$ The theory of consumption value focuses on the consumption values of product and services and explains why consumers either choose or do not choose to buy/consume a particular product or service. This theory has previously been tested in areas such as the dining industry, eco-friendly products and visit intentions and choices of tourism destinations. ${ }^{65}$ Tapachai et al. found that the consumption value theory was fit to measure the beneficial image of a destination. ${ }^{66}$ The conditional value dimension of the consumption value theory denotes a specific situation which leads individuals to buy a product or service. In medical tourism, patients travel outside of their home country due to their medical condition.

A heart bypass surgery that costs around USD $\$ 100,000$ in the USA can be performed to the same level of quality for around USD \$10,000-20,000 at five-star hospitals in various destinations worldwide; ${ }^{2}$ this demonstrates the functional consumption value (i.e. the perceived value for money) of destinations. Kangas also noted epistemic value (i.e. curiosity, novelty and knowledge-seeking behaviours) in the medical tourism decision-making process, as medical tourism can also provide opportunities for patients to explore new regions. ${ }^{32}$

\section{Relationships between Model Factors}

The theory of planned behaviour (TPB) is a theoretical model designed to elucidate the relationships between consumers' beliefs, attitudes, intentions and behaviours. Various studies exploring visit and revisit intentions and the consumption behaviours of tourists based on travel motivations, risks, constraints and destination image have used the TPB hypothesis to support their models. ${ }^{67,68}$ Motivation has been found to have a direct and positive relationship with behavioural intention, indicating that the motivations of medical tourists positively influence their visit intentions. ${ }^{69-72}$ Researchers have also found a strong negative relationship between the perceived risks of travelling and visit/revisit intentions. ${ }^{73-75}$ Disinterest has also been reported to have a significant negative impact on revisit intentions. ${ }^{76}$ Hung et al. argued that higher travel constraints reduces the likelihood of a person travelling. ${ }^{43}$ Lee et al. found that travel constraints and learned helplessness significantly negatively influenced the travel intentions of people with disabilities. ${ }^{77}$
As the sociopsychological motivations of tourists strongly influence the cognitive and affective evaluation of a destination, medical tourists' motivations are assumed to have a positive influence on destination image. ${ }^{25,78}$ Chew et al. identified a significant relationship between perceived risks and destination image. ${ }^{55}$ Bearing in mind that perceived risks directly influence visit intention, this construct can also be argued to negatively influence destination image; however, further studies are needed to fully explore this relationship. While the role of travel constraints on destination image requires further research, an initial study by Chen et al. found a significant negative relationship between travel constraints and destination image in early decision-making. ${ }^{23}$ Destination image has also been noted to have a strong direct relationship with tourist behaviour. ${ }^{79-82}$

\section{Conclusion}

Different factors play important roles in medical tourism. Motivations encouraging patients to travel to a foreign country for treatment vary based on different needs, while perceived risks can influence medical tourists to avoid certain destinations or decide not to travel altogether. Travel constraints may also influence the decision-making of medical tourists and are dependent on factors such as nationality, expense, destination and the presence of existing health conditions. Moreover, the attributes and image of a particular destination can also influence the visit and revisit intentions of medical tourists. This article provides a comprehensive theoretical model of medical tourism decision-making in an attempt to provide a frame of reference for future studies in this field. However, the relationships in this model are relatively complex and many aspects of this complex phenomenon require further empirical research.

\section{References}

1. Debata BR, Patnaik B, Mahapatra SS, Sreekumar K. Efficiency measurement amongst medical tourism service providers in India. Int J Responsible Tour 2013; 1:24-31.

2. Connell J. Contemporary medical tourism: Conceptualisation, culture and commodification. Tour Manag 2013; 34:1-13. doi: 10.1016/j.tourman.2012.05.009.

3. Wongkit M, McKercher B. Desired attributes of medical treatment and medical service providers: A case study of medical tourism in Thailand. J Travel Tour Mark 2016; 33:14-27. doi: 10.1080/10548408.2015.1024911.

4. Patients Beyond Borders. Medical tourism statistics and facts. From: www.patientsbeyondborders.com/medical-tourism-stat istics-facts Accessed: Nov 2016.

5. Association for Tourism and Leisure Education and Research. Medical tourism: A global analysis. From: www.atlas-webshop. org/Medical-tourism-a-global-analysis Accessed: Nov 2016. 
6. Fetscherin M, Stephano RM. The medical tourism index: Scale development and validation. Tour Manag 2016; 52:539-56. doi: 10.1016/j.tourman.2015.08.010

7. Flanigan BE. Medical tourism: Consumers in search of value. From: http://medicaltourisminturkey.org/panel/Panel1/3Delo itte.pdf Accessed: Nov 2016.

8. Crush J, Chikanda A. South-South medical tourism and the quest for health in Southern Africa. Soc Sci Med 2015; 124:313-20. doi: 10.1016/j.socscimed.2014.06.025.

9. Ormond $M$, Sulianti D. More than medical tourism: Lessons from Indonesia and Malaysia on South-South intraregional medical travel. Curr Issues Tour 2017; 20:94-110. doi: 10.1080/13683500.2014.937324.

10. Noree T, Hanefeld J, Smith R. Medical tourism in Thailand: A cross-sectional study. Bull World Health Organ 2016; 94:30-6. doi: 10.2471/BLT.14.152165.

11. Mwijuke G. Rising medical bills sending East African patients abroad. From: www.theeastafrican.co.ke/news/Rising-medicalbills-sending-East-African-patients-abroad/-/2558/2723450//139ke5gz/-/index.html Accessed: Nov 2016.

12. GrossDL.MedicalTourism:India, Thailand, andSingapore.From: www.calhospital.org/sites/main/files/file-attachments/walt er-sullivan-award-dan-gross-7-12.pdf Accessed: Nov 2016.

13. Oh KM, Jun J, Zhou Q, Kreps G. Korean American women's perceptions about physical examinations and cancer screening services offered in Korea: The influences of medical tourism on Korean Americans. J Community Health 2014; 39:221-9 doi: 10.1007/s10900-013-9800-z.

14. Viladrich A, Baron-Faust R. Medical tourism in tango paradise: The Internet branding of cosmetic surgery in Argentina. Ann Tour Res 2014; 45:116-31. doi: 10.1016/j.annals.2013.12.007.

15. Connell J. Reducing the scale? From global images to border crossings in medical tourism. Glob Netw 2016: 16:531-50. doi: $10.1111 /$ glob.12136.

16. Lunt N, Horsfall D, Hanefeld J. Medical tourism: A snapshot of evidence on treatment abroad. Maturitas 2016; 88:37-44. doi: 10.1016/j.maturitas.2016.03.001.

17. Guiry M, Scott JJ, Vequist DG 4th. Experienced and potential medical tourists' service quality expectations. Int J Health Care Qual Assur 2013; 26:433-46. doi: 10.1108/ IJHCQA-05-2011-0034.

18. Wang HY. Value as a medical tourism driver. J Serv Theory Pract 2012; 22:465-91. doi: 10.1108/09604521211281387.

19. Zailani S, Ali SM, Iranmanesh M, Moghavvemi S, Musa G. Predicting Muslim medical tourists' satisfaction with Malaysian Islamic friendly hospitals. Tour Manag 2016; 57:159-67. doi: 10.1016/j.tourman.2016.05.009.

20. Na SA, Onn CY, Meng CL. Travel intentions among foreign tourists for medical treatment in Malaysia: An empirical study. Procedia Soc Behav Sci 2016; 224:546-53. doi: 10.1016/j. sbspro.2016.05.434.

21. Lepp A, Gibson H, Lane C. Image and perceived risk: A study of Uganda and its official tourism website. Tour Manag 2011; 32:675-84. doi: 10.1016/j.tourman.2010.05.024.

22. Klenosky DB. The "pull" of tourism destinations: A meansend investigation. J Travel Res 2002; 40:396-403. doi: 10.1177/ 004728750204000405 .

23. Chen HJ, Chen PJ, Okumus F. The relationship between travel constraints and destination image: A case study of Brunei. Tour Manag 2013; 35:198-208. doi: 10.1016/j.tourman.2012.07.004.

24. Schiffman LG, Kanuk LL. Consumer Behaviour, 8th ed. Upper Saddle River, New Jersey, USA: Prentice-Hall, 2004. P. 45.

25. San Martín H, Rodríguez del Bosque IA. Exploring the cognitive-affective nature of destination image and the role of psychological factors in its formation. Tour Manag 2008; 29:263-77. doi: 10.1016/j.tourman.2007.03.012.
26. Baloglu S, Uysal M. Market segments of push and pull motivations: A canonical correlation approach. Int J Contemp Hosp Manag 1996; 8:32-8. doi: 10.1108/09596119610115989.

27. Crooks VA, Kingsbury P, Snyder J, Johnston R. What is known about the patient's experience of medical tourism? A scoping review. BMC Health Serv Res 2010; 10:266. doi: 10.1186/14726963-10-266.

28. Musa G, Thirumoorthi T, Doshi D. Travel behaviour among inbound medical tourists in Kuala Lumpur. Curr Issues Tour 2012; 15:525-43. doi: 10.1080/13683500.2011.626847.

29. Moghimehfar F, Nasr-Esfahani MH. Decisive factors in medical tourism destination choice: A case study of Isfahan, Iran and fertility treatments. Tour Manag 2011; 32:1431-4. doi: 10.1016/j.tourman.2011.01.005.

30. Deloitte. 2015 health care outlook: Middle East. From: www2. deloitte.com/content/dam/Deloitte/global/Documents/LifeSciences-Health-Care/gx-lshc-2015-health-care-outlookmiddle-east.pdf Accessed: Nov 2016.

31. Rokni L, Pourahmad A, Moteiey Langroudi MH, Rezaeiy Mahmoudi M, Heidarzadeh N. Appraisal the potential of central Iran, in the context of health tourism. Iran J Public Health 2013; 42:272-9.

32. Kangas B. Hope from abroad in the international medical travel of Yemeni patients. Anthropol Med 2007; 14:293-305. doi: 10.1080/13648470701612646.

33. Mansfeld Y, Pizam A. Tourism, Security and Safety: From theory to practice, 1st ed. Oxford, UK: Routledge, 2005. Pp. 27-90.

34. Sönmez SF, Graefe AR. Influence of terrorism risk on foreign tourism decisions. Ann Tour Res 1998; 25:112-44. doi: 10.1016/ S0160-7383(97)00072-8.

35. Yeoh E, Othman K, Ahmad H. Patient-centeredness communication strategy for the medical tourism industry. J Tour Res Hosp 2013; 2:2. doi: 10.4172/2324-8807.1000113.

36. Penney K, Snyder J, Crooks VA, Johnston R. Risk communication and informed consent in the medical tourism industry: A thematic content analysis of Canadian broker websites. BMC Med Ethics 2011; 12:17. doi: 10.1186/1472-6939-12-17.

37. Rodríguez JY, Rodríguez GJ, Morales-López SE, Cantillo CE, Le Pape P, Álvarez-Moreno CA. Saksenaea erythrospora infection after medical tourism for esthetic breast augmentation surgery. Int J Infect Dis 2016; 49:107-10. doi: 10.1016/j. ijid.2016.05.032.

38. Cohen IG. Protecting patients with passports: Medical tourism and the patient protective-argument. Iowa Law Rev 2010; 95:1467-567.

39. Li Z. Attractive forces and risks of international medical tourism: A study based on India. J Chem Pharm Res 2014; 6:125-9.

40. Goldbach AR, West DJ. Medical tourism: A new venue of healthcare. J Glob Bus Issues 2010; 2:43.

41. Crooks VA, Turner L, Cohen IG, Bristeir J, Snyder J, Casey V, et al. Ethical and legal implications of the risks of medical tourism for patients: A qualitative study of Canadian health and safety representatives' perspectives. BMJ Open 2013; 3:e002302. doi: 10.1136/bmjopen-2012-002302.

42. Kangas B. Traveling for medical care in a global world. Med Anthropol 2010; 29:344-62. doi: 10.1080/01459740.2010.50 1315.

43. Hung K, Petrick JF. Developing a measurement scale for constraints to cruising. Ann Tour Res 2010; 37:206-28. doi: 10.1016/j.annals.2009.09.002

44. Smith RW. Leisure of disable tourists: Barriers to participation. Ann Tour Res 1987; 14:376-89. doi: 10.1016/0160-7383(87) 90109-5. 
45. Boyd KM. Disease, illness, sickness, health, healing and wholeness: Exploring some elusive concepts. Med Humanit 2000; 26:9-17. doi: 10.1136/mh.26.1.9.

46. Indian Institute of Tourism and Travel Management. A study of problems and challenges faced by medical tourists visiting India. From: http://incredibleindia.org/lang/images/docs/tradepdf/surveys-and-studies/study-reports/A\%20study\%20on\%20 problems\%20and\%20challenges\%20faced\%20by\%20medical\%20 tourists\%20visiting\%20India.pdf Accessed: Nov 2016

47. Connell J. Medical tourism: Sea, sun, sand and... surgery. Tour Manag 2006; 27:1093-100. doi: 10.1016/j.tourman.2005.11.005.

48. Gartner WC. Image formation process. J Travel Tour Mark 1994; 2:191-216. doi: 10.1300/J073v02n02_12.

49. Echtner CM, Brent Ritchie JR. The measurement of destination image: An empirical assessment. J Travel Res 1993; 31:3-13. doi: $10.1177 / 004728759303100402$

50. Moutinho L. Consumer behaviour in tourism. Eur J Mark 1987; 21:5-44. doi: 10.1108/EUM0000000004718.

51. Gallarza MG, Saura IG, García HC. Destination image: Towards a conceptual framework. Ann Tour Res 2002; 29:56-78. doi: 10.1016/S0160-7383(01)00031-7.

52. Sparks B, Pan GW. Chinese outbound tourists: Understanding their attitudes, constraints and use of information sources. Tour Manag 2009; 30:483-94. doi: 10.1016/j.tourman.2008.10.014

53. Stepchenkova S, Morrison AM. Russia's destination image among American pleasure travelers: Revisiting Echtner and Ritchie. Tour Manag 2008; 29:548-60. doi: 10.1016/j. tourman.2007.06.003.

54. Tasci AD, Gartner WC, Cavusgil ST. Conceptualization and operationalization of destination image. J Hosp Tour Res 2007; 31:194-223. doi: 10.1177/1096348006297290.

55. Chew EY, Jahari SA. Destination image as a mediator between perceived risks and revisit intention: A case of postdisaster Japan. Tour Manag 2014; 40:382-93. doi: 10.1016/j. tourman.2013.07.008.

56. Crooks VA, Turner L, Snyder J, Johnston R, Kingsbury P. Promoting medical tourism to India: Messages, images, and the marketing of international patient travel. Soc Sci Med 2011; 72:726-32. doi: 10.1016/j.socscimed.2010.12.022.

57. Khan MJ, Chelliah S, Haron MS. Medical tourism destination image formation process: A conceptual model. Int J Healthc Manag 2016; 9:134-43. doi: 10.1080/20479700.2016.1142046.

58. Deloitte. Evolving medical tourism in Canada: Exploring a new frontier. From: www2.deloitte.com/content/dam/Deloitte/ca/ Documents/life-sciences-health-care/ca-en-health-care-lifesciences-evolving-medical-tourism-exploring-a-new-frontier. pdf Accessed: Nov 2016

59. Rerkrujipimol J, Assenov I. Marketing strategies for promoting medical tourism in Thailand. J Tour Hosp Culinary Arts 2011; 3:95-105.

60. Al-Hinai SS, Al-Busaidi AS, Al-Busaidi IH. Medical tourism abroad: A new challenge to Oman's health system - Al Dakhilya region experience. Sultan Qaboos Univ Med J 2011; 11:477-84.

61. Yu JY, Ko TG. A cross-cultural study of perceptions of medical tourism among Chinese, Japanese and Korean tourists in Korea. Tour Manag 2012; 33:80-8. doi: 10.1016/j.tourman.2011.02. 002

62. Nadeau J, Heslop L, O'Reilly N, Luk P. Destination in a country image context. Ann Tour Res 2008; 35:84-106. doi: 10.1016/j. annals.2007.06.012.

63. Wish M. Individual differences in perceptions and preferences among nations. In: King CW, Tigert D, Eds. Attitude research reaches new heights. Chicago, Illinois, USA: American Marketing Association, 1971. Pp. 312-28.
64. Lefkoff-Hagius R, Mason CH. Characteristic, beneficial, and image attributes in consumer judgments of similarity and preference. J Consum Res 1993; 20:100-10. doi: 10.1086/209336.

65. Sheth JN, Newman BI, Gross BL. Why we buy what we buy: A theory of consumption values. J Bus Res 1991; 22:159-70. doi: 10.1016/0148-2963(91)90050-8

66. Tapachai N, Waryszak R. An examination of the role of beneficial image in tourist destination selection. J Travel Res 2000; 39:37-44. doi: 10.1177/004728750003900105.

67. Park SH, Hsieh CM, Lee CK. Examining Chinese college students' intention to travel to Japan using the extended theory of planned behavior: Testing destination image and the mediating role of travel constraints. J Travel Tour Mark 2017; 34:113-31. doi: 10.1080/10548408.2016.1141154.

68. Wu K, Raab C, Chang W, Krishen A. Understanding Chinese tourists' food consumption in the United States. J Bus Res 2016; 69:4706-13. doi: 10.1016/j.jbusres.2016.04.018.

69. Baloglu S. The relationship between destination images and sociodemographic and trip characteristics of international travellers. J Vacation Mark 1997; 3:221-33. doi: 10.1177/13 5676679700300304.

70. Yoon Y, Uysal M. An examination of the effects of motivation and satisfaction on destination loyalty: A structural model. Tour Manag 2005; 26:45-56. doi: 10.1016/j.tourman.2003. 08.016 .

71. Park DB, Yoon YS. Segmentation by motivation in rural tourism: A Korean case study. Tour Manag 2009; 30:99-108. doi: 10.1016/j.tourman.2008.03.011.

72. Lo AS, Lee CY. Motivations and perceived value of volunteer tourists from Hong Kong. Tour Manag 2011; 32:326-34. doi: 10.1016/j.tourman.2010.03.002.

73. Floyd MF, Gibson H, Pennington-Gray L, Thapa B. The effect of risk perceptions on intentions to travel in the aftermath of September 11, 2001. J Travel Tour Mark 2004; 15:19-38. doi: 10.1300/J073v15n02_02.

74. Wong JY, Yeh C. Tourist hesitation in destination decision making. Ann Tourism Res 2009; 36:6-23. doi: 10.1016/j. annals.2008.09.005.

75. Simpson P, Cruz-Milán O, Gressel J. Perceived crime and violence: Effects on winter migrants. J Travel Res 2013; 53:597-609. doi: 10.1177/0047287513513162.

76. Huang S, Hsu CH. Effects of travel motivation, past experience, perceived constraint, and attitude on revisit intention. J Travel Res 2009; 48:29-44. doi: 10.1177/0047287508328793.

77. Lee M, Han H, Lockyer T. Medical tourism: Attracting Japanese tourists for medical tourism experience. J Travel Tour Mark 2012; 29:69-86. doi: 10.1080/10548408.2012.638564.

78. Li M, Cai LA, Lehto XY, Huang J. A missing link in understanding revisit intention: The role of motivation and image. J Travel Tour Mark 2010; 27:335-48. doi: 10.1080/10548408.2010.481559.

79. Hudson S. Consumer behavior related to tourism. In: Pizam A, Mansfeld Y, Eds. Consumer Behavior in Travel and Tourism, 1st ed. Oxford, UK: Routledge, 1999. Pp. 7-32.

80. Chen CF, Tsai DC. How destination image and evaluative factors affect behavioral intentions? Tour Manag 2007; 28:1115-22. doi: 10.1016/j.tourman.2006.07.007.

81. Chi CG, Qu H. Examining the structural relationships of destination image, tourist satisfaction and destination loyalty: An integrated approach. Tour Manag 2008; 29:624-36. doi: 10.1016/j.tourman.2007.06.007.

82. Assaker G, Vinzi VE, O'Connor P. Examining the effect of novelty seeking, satisfaction, and destination image on tourists' return pattern: A two factor, non-linear latent growth model. Tour Manag 2011; 32:890-901. doi: 10.1016/j. tourman.2010.08.004. 